\title{
Trust and virtue in banking: the assessment of borrowers by bank managements at the turn of the twentieth century
}

Article

Accepted Version

Newton, L. (2000) Trust and virtue in banking: the assessment of borrowers by bank managements at the turn of the twentieth century. Financial History Review, 7 (2). pp. 177199. doi: https://doi.org/10.1017/S096856500000010X Available at http://centaur.reading.ac.uk/68211/

It is advisable to refer to the publisher's version if you intend to cite from the work. See Guidance on citing.

Published version at: https://www.cambridge.org/core/journals/financial-history-review/article/trust-and-virtue-inenglish-banking-the-assessment-of-borrowers-by-bank-managements-at-the-turn-of-the-nineteenthcentury/E5DA3D524B679A673661165B88D94F7E

To link to this article DOI: http://dx.doi.org/10.1017/S096856500000010X

Publisher: Cambridge University Press

All outputs in CentAUR are protected by Intellectual Property Rights law, 
including copyright law. Copyright and IPR is retained by the creators or other copyright holders. Terms and conditions for use of this material are defined in the End User Agreement.

\section{www.reading.ac.uk/centaur}

\section{CentAUR}

Central Archive at the University of Reading

Reading's research outputs online 


\section{Trust and virtue in banking: the assessment of borrowers by bank managements at the turn of the twentieth century ${ }^{1}$}

First secure an independent income, then practice virtue. (Greek proverb)

Silver and gold are not the only coin: virtue too passes current all over the world. (Euripides, 5th century BC)

Banks are financial intermediaries who mediate between those in financial surplus and those in financial deficit, and between those making and receiving payments. As such, they must manage risk and uncertainty. In doing so, banks require information, most importantly in order to redress the information asymmetries inherent in lending, whereby the borrower knows more about their likelihood to default than the lender. Therefore, crucial in a bank's role as financial intermediary is the ability to extract information from borrowing and potential borrowing customers, in addition to that from the general economic environment, and consequently process the data. This suggests that banks will develop internal systems by which information may be obtained and assessed efficiently. This system of data gathering and processing may be called the 'information structure' of a bank. What is less clear is how information was utilised in making lending decisions.

The paper aims to examine both the perceptions of banks' managements and the procedures undertaken by them in the assessment of borrowing customers in England and Wales at the turn of the twentieth century. To what extent were judgements made on 'subjective' criteria (reputation, social standing, 'virtue', etc.) or 'objective' criteria (financial statements, profits, accumulated wealth of partners, etc.)? Was a customer's 'reputation' important in banks' assessment of their creditworthiness and did the perceptions of 'reputation' change over time? How was 'reputation' defined? Did the amalgamation movement and consequent

I would like to thank Edwin Green and Sara Kinsey at HSBC Group Archives and Fiona McColl and Susan Snell of the NatWest Group Archives for their assistance in writing this paper. Thanks must also go to Judith Wale for generously allowing the use of her unpublished material and to those who provided such helpful comments on earlier drafts this paper at the Business History Conference 1999; the Monetary History Group; and the Conference of the Association of Business Historians, South Bank University. 
concentration in banking lead to a radical overhaul in the 'information structure' of banks? Did an increasingly centralised structure impose a uniform policy which branches were required to follow? Did personalised banking, which had efficiently utilised local knowledge over the previous centuries, disappear in the headlong rush for size and a London head office? Or were the larger-scale banks, with their greater resources, better able to collect and process information effectively? As the century progressed, the use of formal accounting measures increased, but did this replace the use of 'subjective' judgements of customers?

An attempt has been made to answer these questions by examining the archives of banks operating around the turn of the century, from c.1870 to c.1920. Due to the volume of information, sampling has been necessary. Moreover, the sample is somewhat skewed as the records examined are those of banks which survived and were ultimately amalgamated into what became the 'Big Five' banks by 1920 . However, there were very few bank failures after 1878 which offsets this bias. Moreover, previous experience of consulting bank archives for the earlier part of the nineteenth century has also been drawn upon.

The type of archives consulted were 'Opinion' and 'Character' books. Banks used 'Opinion' books to collate information regarding customers which had been gathered from various parties - for example, bank directors, bank managers, suppliers of the potential client, or another bank on which bills had been drawn. 'Character Books', ledgers designed to provide information relating to the status of the client, were also collated. Moreover, contemporary banking literature published in order to provide guidance for banking professionals, such as the Bankers Magazine, will also be examined. Although the research conducted for this paper cannot claim to be in any way exhaustive, the author is confident that the archives and sources examined offer a reasonable representation of assessment practices carried out by banks when applications for credit were made. Moreover, the findings for this study have been used in conjunction with theoretical literature in an attempt to expand the analysis of bank decision-making. 
The paper will focus upon the 'subjective' assessment of potential borrowing customers of banks in the late nineteenth and early twentieth centuries. 'Objective' assessment criteria will also be considered but primarily with reference to their use in conjunction with 'subjective' information. Moreover, analysis will be qualitative rather than quantitative in nature, reflecting the character of the sources consulted. The paper will examine some of the theory surrounding 'subjective' information; the background of banking developments during the period under consideration; methods and criteria by which bank customers were assessed; and finally offers some conclusions.

\section{I}

The traditional principles of banking involved bank managements assessing and spreading risk. $^{2}$ In 1928 Sykes identified the four key principles of banking as 'safety', 'adequacy', 'economy' and 'efficiency'. ${ }^{3}$ In lending money to customers, arising risks could be reduced by collecting information in order to assess the creditworthiness of a customer and possibly a specific project for which accommodation was required. The examination of how banks utilised information in the process of making lending decisions is fraught with problems. The difficulty lies in the collection and interpretation of evidence. Banks are naturally reluctant to reveal such information: the bank which possessed an efficient mechanism for assessing borrowing customers would have an obvious advantage over others in the lending market. Moreover, the interpretation of information is specific to the late nineteenth and early twentieth centuries when late twentieth century perceptions did not apply.

Despite these difficulties, an attempt has been made here to examine the criteria which were used to assess clients who applied for credit from the bank, particularly the 'subjective' information utilised by the banks. For example, the concept of 'virtue' as applied to a borrowing customer has been examined. 'Virtue' may be defined as 'worth; moral

2 P. Mathias, 'Capital, credit and enterprise in the industrial revolution', Journal of European Economic History, 2 (1973), p. 142; L. Pressnell, Country Banking in the Industrial Revolution (1956).

3 Jospeh Sykes, The present state of joint stock banking (1928). 
excellence; good quality, especially moral'. ${ }^{4}$ Maitland, in his examination of virtue in the economic environment, argues that 'effective functioning of the economy depends on moral virtues that economic actors bring to the market place' and that virtue counteracts the destructive influence of the market (which promotes self-interest) upon society and the economy. ${ }^{5}$ Hirsch identifies social virtues as: truth, trust, acceptance, restraint and obligation. ${ }^{6}$ Indeed, trust in business transactions, but especially in lending transactions, remains essential in a modern environment. ${ }^{7}$

Reliance upon external measures to guarantee trust, for example contracts and law courts, was expensive, thus transaction costs would increase if such methods were utilised. Fukuyama asserts that 'If people who have to work together in an enterprise trust one another because they are all operating according to a common set of ethical norms, doing business costs less'. ${ }^{8}$ Therefore, the use of reputations and trust may have reduced costs for the banker. However, an element of moral hazard would remain. Why should a borrowing customer of a bank not transgress if it was in their economic interest? This is where honesty, trustworthiness and self-control may have moderated economic self-interest. Those in business may have sought to maintain their virtuous reputation, and therefore their trustworthiness, as it was in their self-interest: the reputation for being trustworthy was likely to have created business opportunities and, in the case of bank lending, may have increased the likelihood of gaining access to credit. Maitland asserts that virtues are a source of economic benefit to those who possess them as 'virtues (or the reputation of having them) may create valuable future business opportunities'. ${ }^{9}$ Conversely, a 'bad' reputation gained

$4 \quad$ Chamber Concise Dictionary (1990).

5 Ian Maitland, 'Virtuous markets: the market as school of the virtues', Business Ethics Quarterly, Vol. 7 Issue 1, 1997, pp. 17-18.

$6 \quad$ Fred Hirsch, Social Limits to growth (1978).

7 For a full and fascinating analysis of the issue of trust in an economic environment see F. Fukuyama, Trust: the social virtues and the creation of prosperity (1995). For a discussion of trust in contemporary banking see A. Berry, S. Faulkner, M. Hughes and R. Jarvis, Bank lending. Beyond the theory (1993), p. 92.

8 Fukuyama, Trust, p. 27.

9 Maitland, 'Virtuous markets', p. 22. 
by an individual who failed to co-operate in business, repay debts, etc. may be ostracised from a business environment and therefore find it very difficult to trade profitably. ${ }^{10}$

Thus, in business the future was a very important consideration as actors in the economy were forced to project forward in order to consider future transactions. ${ }^{11}$ This is neatly summarised by David Hume in his A Treatise of Human Nature (1740).

I learn to do service to another, without bearing him any real kindness: because I foresee, that he will return my service, in expectation of another of the same kind, and in order to maintain the same correspondence of good offices with me or others. And accordingly, after I have serv'd him and he is in possession of the advantage arising from my actions, he is induc'd to perform his part, as foreseeing the consequences of his refusal. ${ }^{12}$

Maitland argues that participants in the economy are forced to consider the impact that their behaviour may have upon future transactions and therefore opportunistic behaviour is prohibited. This was, and is, especially true of bank/business relations which may be extended over a period of time. Long-term relationships between banks and customers were likely to develop trust between the two parties, if the actors behaved in a trustworthy manner and, specifically, if customers repaid their debts. The length of a bank's relationship with the customer was also crucial in information gathering: the longer a customer was with a bank, the more information about them may have been accumulated and a better assessment of their creditworthiness made. ${ }^{13}$ Thus an information advantage was created. As a consequence, existing customers of the bank with a 'virtuous' reputation and track record of repayment may have been granted credit more freely than new applicants with no history at the bank or branch. ${ }^{14}$ Williamson concurs, asserting that repeated transaction with the same

10 See M. Ridley, The origins of virtue (1996), pp. 80-82 and P. Kitcher, 'The evolution of human altruism', Journal of Philosophy, 90, 1993, pp. 497-516.

11 Axelrod talks of the 'shadow of the future' in The Evolution of Co-operation (NY, 1984).

12 David Hume, A Treatise of Human Nature (1740).

13 For a discussion of screening and monitoring by banks see Lucy Newton, 'Domestic Institutional change: English and Welsh joint stock banking, 1826-1860' in P. L. Cottrell (ed.), Finance and the making of the modern capitalist world (forthcoming) and Francesco L. Galassi, 'Screening, Monitoring and Incentives in Co-operative Banks: the case of Italy's Casse Rurali, 1883-1926, University of Leicester discussion papers in Economic and Social History, No. ESH96/2, Nov. 1996.

14 F. Capie and M. Collins, 'Industrial lending by English commercial banks, 1860s-1914: why did banks refuse loans?' Business History, Vol. 38, No. 1, 1996. 
partners may be a source of significant economic advantage. ${ }^{15}$ Furthermore, Mayer has emphasised that long-term, close bank/industry relationships may reduce moral hazard. Such relationships, he argues, form a commitment which may replace long-term, written contracts as the latter are often not feasible. ${ }^{16}$

The assessment of customer's 'virtue' and trustworthiness by the banks, and its application to lending decisions, may be described as the 'reputation' approach. ${ }^{17}$ However, banks also used 'objective' sources of information, such as company balance sheets, profit and loss accounts, the value of property owned by a customer, etc., in order to assess their customer's creditworthiness. What the remainder of this paper will try to discover is whether such assessment criteria changed over the turn of the century, as banks became more concentrated, and which set of information was the more important - 'objective' or 'subjective'. Firstly it is important to consider the changes which occurred in the banking sector during the period under consideration.

\section{II}

From their inception in 1826 until the 1870s, joint stock banks in England and Wales conducted business on a very localised level and of a personalised nature. There were some regional banks but very few national institutions. The promotion of extra-regional banks, which meant in practice the extension of business into the provinces from London-based banks, only really developed after 1860. In 1874 only two banks had major branch networks: the London \& County with 149 offices and agencies, and the National \& Provincial with 138, while, on average, joint stock banks had still but 10.5 branches.

15 Oliver E. Williamson, 'The economics of organisation: the transaction cost approach', American Journal of Sociology, Vol. 87 (1981), pp. 548-577.

16 C. Mayer, 'New issues in corporate finance', European Economic Review, 32, 1988, pp. 1167-88.

17 Monika Pohle, 'Risk, information and noise: risk perceptions and risk management of French and German banks during the nineteenth century', Financial History Review, Vol. 2, Part 1, April 1995, p. 32 . 
Directors of a typical joint stock bank - relatively small with few branches - were often businessmen themselves, involved in local industry and commerce, and were therefore involved in local business networks. These directors were able to utilise their personal knowledge and participation in local business networks in order to assess their borrowing customers. ${ }^{18}$

However, during the second half of the nineteenth century, the business and economic environment became increasingly sophisticated and operated on such a magnitude that small-scale, localised banking could no longer cope with the demands of its commercial and industrial customers; they could no longer provide the volume of finance required. Joint stock banks in England and Wales responded to these changes by amalgamating in order to achieve physical and financial growth. Amalgamations accelerated from the 1860s onwards, with the peak of merger activity occurring in the late 1880 s and early 1890 s - between 1880 and 1894 a total of 69 mergers took place ${ }^{19}$. Another surge of merger activity occurred in the decade leading up to the First World War. The result was that the number of joint stock banks fell from a peak of 128 in 1880 to only 65 by 1905 and the total number of banks fell from 600 in 1825 to 70 by $1913 . .^{20}$ Amalgamations did not stop during the First World War and the emergence of the 'Big Five' in 1918 - Barclays, Lloyds, National Provincial, Midland and The Westminster - was the culmination of concentration in banking in England and Wales which established the structure of domestic banking for the next 50 years. ${ }^{21}$

18 See Lucy Newton, 'Regional bank-industry relations during the mid-nineteenth century: links between bankers and manufacturers in Sheffield', Business History, Vol. 18, No. 31996 and idem. 'Domestic Institutional change'.

19 M. Collins, Money and Banking in the UK: a history (London, 1988), pp. 78-9.

20 See Joseph Sykes, The Amalgamation Movement in English Banking, 1825-1924 (London, 1926); S. Nishimura, The Decline of Inland Bills of Exchange in the London Money Market 1855-1913 (Cambridge, 1971), p. 6; Collins, Money and Banking, p. 78; F. Capie and G. Rodrik-Bali, 'Concentration in British Banking 1870-1920', Business History, 24 (1982); and Lucy Newton, 'Concentration and internationalisation in banking, 1880-1920' in Sara Kinsey and Lucy Newton (eds.), Banking in an age of transition (1998).

21 Mergers also allowed banks to increase in size and expand their branch networks relatively quickly and cheaply - the costly investment involved in establishing new premises and organisations being avoided. Amalgamations provided 'a means of business expansion which, without a large expenditure in the institution of branches, is not otherwise possible', Bankers Magazine [hereafter BM], 1889, p.385. 
The development of large-scale, branch banking meant that process of collecting and processing information became outdated. Personalised channels of information were no longer as effective and thus the information structure of banks was becoming obsolete. ${ }^{22}$ Branches could still operate at a local level but banks in England and Wales were becoming increasingly centralised towards the end of the century. What may have been described as 'relationship' banking appeared to be in the process of being superseded by what may be called 'transaction' banking. ${ }^{23}$ Indeed, concentration via amalgamations had the benefit of economies of scale, as costs for a large combine were reduced upon introducing more efficient, centralised management and operating systems. Banks actively reformed their management systems following amalgamation rather than allow separate constituent banks to continue operating autonomously. ${ }^{24}$

Moreover, banking itself was becoming an increasingly professionalised occupation. The Institute of Bankers in Scotland was founded 1875 and the Institute of Bankers was established in $1879 .{ }^{25}$ Such professional bodies reflected a pull in the standardisation of banking practice; the need to cope with expanding numbers of customer and staff required such developments. ${ }^{26}$

Great concern was expressed by contemporaries that such centralisation would affect the lending practices of joint stock banks and much consequent research has attempted to analyse the impact of concentration in banking upon lending, especially to small-scale and industrial customers. ${ }^{27}$ The new, large-scale, centralised banks, it was argued, took much of

22 Marco Da Rin, 'Understanding the development of German Kreditbanken, 1850-1914: an approach from the economics of information', Financial History Review, Vol. 3, April 1996. p. 34.

23 Ian Morison, 'Moral conflicts in commercial banking' in S.F. Frowen, and F.P. McHugh (eds.), Financial decision-making and moral responsibility (Macmillan, 1995). p. 57.

24 A. R. Holmes and Edwin Green, Midland. 150 years of banking business (London, 1986), pp. 109112; Francesca Carnevali, 'Finance in the regions: the case of England after 1945' in Y. Cassis, G. Feldman, and U. Olsson, (eds.), The Evolution of Financial Institutions and Markets in TwentiethCentury Europe (Aldershot, 1995).

25 Edwin Green, Debtors to their profession: a history of the Institute of Bankers, 1879-1979 (1979)

26 Holmes and Green, Midland, p. 64.

27 For example, Carnevali, 'Finance in the regions'; Y. Cassis, 'Management and Strategy in the English Joint-Stock Banks, 1890-1914', Business History, 27. (1985); Y. Cassis, 'Financial Elites in Three European Centres: London, Paris, Berlin, 1880s-1930s', Business History (1991); P.L. Cottrell, 
the power to make lending decisions away from the local manager and instead lending policy was decided at a head office in London where there was limited appreciation of local or regional needs. In this new system, the close personal monitoring of clients by bank directors was no longer feasible. Bank managements also needed national knowledge of a more complex economic environment. This resulted in the adaptation of the bank's 'information structure'. Da Rin contends that 'impersonal credit markets have less monitoring power due to the distance of financial intermediaries from their customers'. ${ }^{28}$ Morison maintains that in the process of developing economic sophistication, relationship banking gave way to transaction banking, and that the bond of trust between banker and customer was loosened as a result. ${ }^{29}$ Yet bank managers at branch level would have been able to continue local monitoring, even if centralised directors did not. Did branches of the large joint stock banks manage to maintain their personal links with business? Or did the new centralised decision-making process, whereby branch managers reported to the directors at a head office in London, result in more conservative lending practices? This paper will now go on to examine the assessment of information pertaining to borrowing customers of the banks over the turn of the century when such major changes where taking place.

\section{III}

How did banks assess potential borrowing customers? Firstly, the reputation approach, discussed above, may have been taken in which 'subjective' criteria were used such in assessment procedures. ${ }^{30}$ Secondly, banks could undertake an assessment of tangible assets, or rather the examination of 'objective' criteria, for example, balance sheets, existing debt, company profits and turnover, levels of personal wealth of partners or directors, etc. An examination of the 'reputation' approach taken by banks at the turn of the century will initially be made, and this will provide the focus for the remainder of this paper.

Industrial Finance 1830-1914: The finance and organisation of manufacturing industry (London, 1979), pp. 237-9; P.L. Cottrell, The domestic commercial banks and the City of London, 1870-1939' in Y. Cassis (ed.), Finance and Financiers in European History, 1880-1960 (Cambridge, 1992), pp. $52-$ 59; Holmes and Green, Midland., pp. 115-7.

28 Da Rin, 'Understanding the Kreditbanken', p. 30.

29 Morison, 'Moral conflicts in commercial banking', p. 57.

30 Pohle, 'Risk, information and noise', p. 32. 
Trust, confidence and personal relations remained an important part in banking, even as it increased in size and centralisation. Indeed, in the modern business world, reputation is recognised as a form of 'warranty' and is especially important to knowledge-based institutions such as banks. ${ }^{31}$ In the case of French and German banks in the nineteenth century, Pohle has argued that the 'reputation approach' was paramount in assessing borrowing customers.

When bankers resorted to older methods of appraisal, information for a transaction (such as balance sheet data and technical assessment) was completely replaced by information about the personal reputation of business partners and technical experts. ${ }^{32}$

Such reputation, Pohle argued, was based upon bourgeois values. Moreover, even the first credit rating agency, established in 1841, 'mainly gathered information of the character traits and personal habits of businessmen, rather than operational data of their firms.' ${ }^{33}$ Indeed, the examination of English and Welsh bank archives demonstrates that bankers relied upon 'reputation' in the early twentieth century. Bank managements repeatedly comment on their borrowing customer's 'undoubted' or 'doubtful' reputation.

When considering 'subjective' methods of credit appraisal, it is important to bear in mind the implicit values utilised by bankers in late nineteenth and early twentieth century England and Wales when assessing their customer's reputations. No formal questionnaire has been found which details the opinions or judgements on which decisions were made by bank managements about their customers. Appendix A shows a set of criteria which was used by the National Provincial Bank in the early twentieth century which includes 'character and connection' but does not indicate how 'character' was assessed. Yet an implicit, if not explicit, set of criteria appears to have been utilised when assessing customers 'subjectively' and these criteria were used through the late-nineteenth and into the twentieth century. The recurring language found in the archival material of the banks describes 'good' or 'virtuous'

31 Furthermore, it has been recognised in recent literature that reputations, in helping a company obtain credit, can decrease the costs of a firm. C.J. Fombrun, Reputation. Realizing value from corporate image (1996), p. 3 and pp. 75-6.

32 Pohle, 'Risk, information and noise', p. 34.

33 ibid. 
customers as 'sound', 'safe', 'reliable', 'steady', 'responsible', 'respectable'. ${ }^{34}$ Other frequently used adjectives include 'industrious' and 'thrifty' - reflections of the traditional Protestant work ethic. ${ }^{35}$ This appears to be the language of 'virtue' as far as the bank is concerned. However, whilst viewing data from late twentieth century, historians must be aware that perceptions concerning language and judgements from an earlier period will necessarily differ.

In assessing such virtuous qualities, the length of the relationship between bank and customer was very important. Banks were likely to develop relationships with their clients over a period of time in order to ensure that there was a sufficient flow of information on which decisions could be made. Indeed, it has always has been far easier for a bank to assess a long-standing customer than a new client due to the accumulation of information about the former which a bank may draw upon, in addition to the establishment of trust between the two parties. The accumulation of knowledge by a bank concerning its existing customers occurred through the processes of observation and monitoring. Extended relationships between bank and client also had the benefit of reducing the costs of monitoring. ${ }^{36}$

References to the length of a client's time with a bank are to be frequently found in the archives. By 1908, a hosier in the East End had banked with the Whitechapel branch of Midland Bank for 25 years, a fact that was commented upon by the manager when offering any opinion regarding the client. During this time the bank had obviously been able to monitor his account: the manager recorded in 1910 that 'we see transactions on his a/c to the extent of your figures in a well spread series'. ${ }^{37}$ Branches of the National Provincial

Such language appears to confirm the conservative character of bankers, especially British bankers.

See M. Weber, The Protestant ethic and the spirit of capitalism (London, 1930).

See Newton 'Domestic Institutional change'.

HSBC Group Archives [hereafter HSBCGA]: Midland Bank [hereafter MB], Whitechapel branch, Opinion Book, 546, 9th Mar. 1908 and 23rd Apr. 1910, f.28. 
bank also refer to 'a reliable old client', 'an old and valued customer', 'old respectable and substantial customers', 'one of our oldest and best clients'. ${ }^{38}$

There is also evidence that a long relationship with the bank could prove to be beneficial to the customer with regard to obtaining credit. Banks appeared to be quite flexible with the credit facilities of established borrowers and this conforms with the theoretical literature discussed in section I. A firm of corn merchants who banked at the Brighton branch of the National Provincial were described as 'old and valued' customers but also ones who 'occasionally exceed the sanctioned limit without notice'. However the manager asserted that they were 'considered good.' Another customer at the same branch was again referred to as 'old and respectable' and, despite the firm occasionally exceeding 'sanction when purchasing cargoes of wheat (without notice)', were 'considered quite responsible.'39 When discussing a farmer banking with a Wiltshire branch of the National Provincial, the Manager described a man 'seriously pinched by a large debt'. However, the farmer was an old and trusted customer of the bank and one who, the Manager believed, 'with better times likely to do well'. 40 This conforms with the findings of other historians. In her study of business and banking in Yorkshire between 1750 and 1850, Hudson states that 'if a manufacturer gained respectable status he could be assured of continuing support from institutions of the capital market and from lenders or suppliers even in hard times.' ${ }^{14}$

Monitoring customers could aid the banker in avoiding future provision of credit to customers who were unlikely to repay or for projects that were not viable. Monitoring could also be used to punish 'bad' behaviour. In 1924 a client of Midland Bank was described

38 NatWest Group Archives [hereafter NWGA]: National Provincial Bank [hereafter NPB], Tunstall Branch, character book, 9966, f.29, 16th Jan. 1903; Brighton Branch, Information Book, 20521, Apr. 1907, f. 39 and f. 10; Berkeley Branch, Character Book 21218, 3 May 1883, f.59.

39 NWGA: NPB, Brighton Branch, Information Book, 20521, June 1906, f. 18 and July 1906 f. 10.

40 NWGA: NPB, Tunstall Branch, character book, 9966, 4th Jan. 1881, f. 3. In additional to being long-standing customers, it is important to note that the above mentioned were also 'doing substantial business', had collateral security deposited at the bank, or owned property and stock of substantial value.

41 P. Hudson, The genesis of industrial capital. A study of the West Riding wool textile industry c. 17501850 (1986), p. 269. 
thus: 'He has conducted his a/c here so unsatisfactorily that we have had to write and warn him that we would have to close his a/c unless he improves'. ${ }^{42}$ However, the assertion made by a modern economist that 'monitoring the firm's characteristics, i.e. a creditworthiness test, makes it possible to avoid bad loans'43 clearly had no basis in reality for the late nineteenth/early twentieth century banker. Perfect information - certainty made possible through acquiring primary information - was not an attainable goal and therefore banks could make incorrect business decisions. External circumstances could, obviously, also intervene to damage a previously healthy business. Indeed, despite their best efforts and experience and despite screening and monitoring borrowing clients, banks could, and did, make unsuccessful decisions. In 1909 a shoe manufacturing firm in East London, who had been with the bank since 1868 and was described as 'very respectable', 'trustworthy', 'good for' rent of 65 pounds per annum and running a successful business, went bankrupt. ${ }^{44} \mathrm{~A}$ recent text on modern corporate finance states: 'Like all financial decisions, credit allocation involves a strong dose of judgement' ${ }^{45}$ These judgements could be misguided.

The need for monitoring and the use of the 'reputation' approach was accentuated under certain circumstances, for example when banks provided credit upon which no collateral security was deposited. This was a frequent practice in nineteenth and early twentieth century banking. Capie and Collins estimate from their research on banking between 1870 and 1914 that 'over half of the industrial overdrafts made in the provinces did not involve the formal deposit of securities: they were made either wholly unsecured or relied on the signing of personal guarantees'.46 In an examination of banks in the first half of the nineteenth century, Newton found that 30 per cent of credit extended by provincial banks in a sample were unsecured or extended on the basis of personal guarantees. ${ }^{47}$ Wale, in her study of the Leicestershire Banking Company in the late nineteenth century, revealed that 28 per cent of

\footnotetext{
42 HSBCGA: MB, Whitechapel branch, Opinion Book, 546, 11th Mar. 1924.

43 T. Broecker, 'Credit-worthiness tests and interbank competition', Econometrica, 58 (1990), pp. 429-52.

44 HSBCGA: MB, Whitechapel branch, Opinion Book, 546, 20th Apr. 107 to 1909, f.124.

45 R.A. Brealey, and S.C. Myers, Principles of corporate finance (1996), p. 860.

46 Capie and Collins, 'Industrial lending', p. 35.

47 See Newton, 'Domestic Institutional change'.
} 
overdrafts extended between 1896 and 1898 were secured by a customers 'personal responsibility', or rather no formal collateral security. ${ }^{48}$ Alternatively, the customer may have been unwilling to provide financial (objective) information about their business and thus past experience and 'reputation' became crucial. In 1903 a customer of the Tunstall Branch of the National Provincial Bank is described as a 'highly respectable and reliable old client' with 'an old established and regular business' but also one who had a 'very touchy temperament and will not give estimate of his means. ${ }^{149}$

Did bankers in England and Wales at the turn of the century place such emphasis on customer's reputation and 'virtue' that it obscured other assessment criteria, as Pohle's example demonstrates? The author argues that it did not. In appraising their customers, bank records create the impression that reputation is paramount. The language which dominates these records is that of customer 'soundness', 'safety' and 'reliability' - traits of virtue. Yet other criteria were also being utilised by the banks in order to assess creditworthiness: 'virtue' was not the sole criteria on which a potential borrowing customer was judged.

Indeed, the discussion of reputation may sometimes be misleading. With such interpretation the historian must obviously be wary about interpreting language and judgements from an earlier period which will necessarily be infused with different meanings. Moreover, the language and perceptions found in the bank archives would appear to differ from those of contemporaries in a non-business or non-banking environment. An excellent illustration of this has been found by examining the 'Opinion Book' of the Whitechapel branch of Midland Bank. The records of one particular customer from 1908 onwards describe the business partners as 'trustworthy' and 'respectable'. This firm of rag merchants had been banking at the branch since 1898. They met 'their engagements promptly' and in applying for credit of

\footnotetext{
48 Judith Wale, 'What help have the banks given British industry? Some evidence on bank lending in the Midlands in the late nineteenth century', Accounting, Business and Financial History, Vol. 4, No. 2, 1994, pp. 329-331. 
between $£ 50$ and $£ 500$ repayment was described as being 'well within their usual engagements'.50 However, the commentary also included the information that the two partners (brothers in the same firm) had recently undertaken six months hard labour for handling stolen property. This information is recorded twice in the 'Opinion Book' and is followed by further descriptions of the brothers' 'respectability' 'means' and 'standing'. It appears that the business was indeed very sound and profitable and that the bank enjoyed a relatively long-term and prosperous relationship with these customers. ${ }^{51}$ Thus, the business clients could be assessed as 'undoubted' and 'trusted' in that they were proven to be reliable re-payers of any credit extended. The same language could not be applied to them outside of this very narrow assessment criteria, or rather in the wider world where they had been convicted for criminal activity. Six months hard labour would, presumably, be viewed in early twentieth century British society with some stigma. However, such a sentence appears to have elicited a rather understated response from the bank. This example illustrates that the ultimate assessment of this customer by the bank concerned their ability to repay credit: this was the 'reputation' that mattered to a bank. Such virtue may be described as one of business rather than morality.

This again conforms with the findings of Hudson in her examination of early nineteenth century business and banking in West Yorkshire.

Being respectable had little to do with social morality but everything to do with property and a reputation for regularity in paying debts and avoiding speculation. The 'respectable' were the propertied, ...... the well known in the neighbourhood, the native, the naturalised or the long-resident and those who avoided accommodation or bills or similar improper commercial dealings. ${ }^{52}$

Hudson concludes that the one enduring feature of nineteenth century business and access to credit 'appears to have been the importance of maintaining trusted, respected and propertied status in the eyes of the local business community.' 53

\footnotetext{
50 HSBCGA: MB, Whitechapel branch, Opinion Book, 546.

51 The brothers moved their account in 1914 after 16 years with the branch.

52 Hudson, Genesis of industrial capital, p. 269.

53 ibid., p. 270.
} 
Indeed, when examining the records more closely, the word 'safe' is frequently qualified by 'for that amount'; 'responsible' is combined with 'for the figures'; and 'trustworthy' is given the proviso 'for the quotation'.54 A customer of the National Provincial in Brighton was described in 1906 as 'respectable, trustworthy' but also 'possessed of some means'. ${ }^{55}$ Thus these value judgements are being made with regard to business criteria: the ability or responsibility of the client to repay the credit applied for.

A comment concerning a customer of the Whitechapel branch of Midland Bank illustrates that the manager considered the applicant 'trustworthy for business engagements' or 'trustworthy in the way of business'. A woman running a boot and shoe manufacturing company was described as 'respectable judging from the turnover on the company's a/c'. ${ }^{56}$ In Wiltshire, National Provincial customers are described as 'respectable' and 'trustworthy' but these adjectives are combined with 'industrious', 'understands his business' or a 'keen man of business'..$^{57}$ These comments explicitly defined the parameters of a customer's 'virtue': judgement was being made in the business rather than moral sense of the word. ${ }^{58}$ Conversely, at the Worcester branch of the National Provincial Bank a Character Book describes a customer who owned and ran a stationery business as 'very respectable steady and reliable but not a very good man of business'. ${ }^{59}$

Furthermore, information considered by the banks which may at first glance appear to be indicators of moral or social virtue would also have been motivated by a practical business sense, or objective assessment. Rich relatives could enhance reputation and status but also provide 'objective' criteria for assessment. A draper in Southsea is described as having 'a well to do Uncle who would assist him in case of need'. ${ }^{60}$ The bank was clearly including a third party in its credit assessment who could act as guarantor or financial saviour in times of

\footnotetext{
54 HSBCGA: MB, Whitechapel branch, Opinion Book, 546, 7th Feb. 1905 and 27th Mar. 1906, f.25.

55 NWGA: NPB, Brighton Branch, Information Book, 20521, June 1906, f. 18.

56 ibid., comments from 1910-1911, f.57.

57 NWGA: NPB, Berkeley Branch, Character Book 21218, f. 3, 1879, 1881.

58 ibid., 27th Jan. 1908, f.26.

59 NWGA: NPB, Worcester Branch, Character Book 20688, f. 12, 1903.

60 NWGA: NPB, Southsea Branch, Character book, 21254, f.109, 12th Mar. 1907.
} 
need. In this case the bank is explicit in naming alternative sources of familial finance but elsewhere banks merely refer to relatives with property or businesses.

The Southsea branch of the National Provincial Bank also recorded the philanthropic activities of a customer: 'Gives a good deal to charities. Highly respected and trustworthy.'61 However, although such charitable activity may be viewed as morally 'virtuous' it also provided an indication that the customer had enough money to distribute to worthy causes and therefore was likely to have the means to repay credit. The 'Book of Instructions' (1914) of the National Provincial Bank provides guidance to its staff which may also be considered indicators of behaviour that the bank saw as 'virtuous' or, conversely, 'sinful': 'Habits such as intemperance, betting or gambling of any description,......or speculation in any securities, are expressly forbidden.'62 Again, such moral guidance reflected sound business principals on the part of the bank. It was quite possible that similar guidelines may have been extended to their customers behaviour, in which case those who drank to much, gambled or speculated were likely to be high risk borrowers in the eyes of any bank. The bank would be more interested in the impact that such activities had upon a customer's business performance rather than upon their spiritual well-being.

Through an examination of the bank records it became clear that despite a discussion of a potential borrowing customer's reputation for 'soundness' and trustworthiness, a clear and 'objective' assessment of their ability to repay was also being considered. Thus, reputation remained important, but a customer's ability to repay was ultimately just as important, if not the most important criteria.

Indeed, the 'reputation' approach was combined with more practical, pragmatic and 'objective' judgements, further to those considered above. Objective assessment of potential customer's creditworthiness by banks may be viewed as a system of 'credit-rating'. Modern

\footnotetext{
61 ibid., f.85, 20th Feb. 1903.

62 NWGA: NPB, Book of Instructions, 1914, 6492, f. 5.
} 
techniques of assessing a customer's likelihood of repaying credit may involve a mechanical scoring system utilised by a credit rating agency in order to pre-screen applications. These credit-scoring systems are based on assessments of income, property owned and overall financial position. ${ }^{63}$ In the past, this role could be undertaken by the branch manager, although in a less formalised manner. ${ }^{64}$

In the process of 'credit-rating', banks frequently examined business customer's financial records. A potential customer's financial position could be assessed by examining balance sheets and accounts, by considering the volume of turnover of a business, or the level of debt a customer had already amounted. Personal wealth was also assessed. Finally, the call for collateral security remained a safe and reliable method by which a bank could reduce the risk inherent in lending.

The scrutiny of accounts and balance sheets of those who applied for credit was common banking practice and remained so into the twentieth century. Indeed, by the end of the nineteenth century professional accountants were increasingly being used by banks in order to assess the financial information of potential and existing borrowing customers. ${ }^{65}$ Balance sheets would show a company's stock levels, level of debt, assets, liabilities and debt/equity ratio, all of which could be useful to the banker involved in the assessment of creditworthiness. ${ }^{66}$ However, in the archives consulted for this study it is often unclear how banks utilised such financial information in the final decision to extend credit facilities or withhold them. The Instruction Book of the National Provincial Bank from 1914 does not provide a great deal more clarity: 'Balance sheets (audited for preference).....should be scrutinised carefully and attention drawn to any variations of movement or unusual features.'

63 Brealey and Myers, Principles of corporate finance, pp. 852-854.

64 Moreover, credit rating systems are not purely modern phenomenon. Specialist agencies were also available to nineteenth century bankers. 'The exchange of opinion on credit-worthiness was a long established feature of contact between banks but by the late 1870s specialist agencies were also in demand.' Holmes and Green, Midland, p. 64.

65 Judith Wale, 'A neglected aspect of the growth of the accountancy profession: the role of English deposit banks in providing new work for accountants, 1880-1914', unpublished paper.

66 Moreover, balance sheets were an indication that company accounts were actually being kept and thus may be viewed as having promoted the perception of financial efficiency or confidence. 
It also (unsurprisingly) cautioned: 'be suspicious with regard to abnormal turnovers and large withdrawals of cash'.67 The bank appeared to be looking for figures which fluctuated wildly or indicated any difficulties in the business of a customer as indicators of risk. It would be possible to speculate that a healthy balance sheet could be an indicator of a healthy company but the unreliability of such financial data during this period, especially when used for public consumption, could limit its value.

Highlighting the usefulness of financial data, Wale argues that the regular collection of such information by a bank could provide 'an early warning that a customer might have difficulty in wiping out or reducing the firm's overdraft' ${ }^{68}$ Furthermore, it was in the interests of business customer to provide credible financial information in order 'to persuade the bank to renew an overdraft facility' and certainly the provision misleading accounts or balance sheets would be detrimental to the establishment of a fruitful and long-tern relationship with a bank. ${ }^{69}$ Furthermore, the amalgamation movement at the end of the nineteenth century led to greater formalisation in the use of customer financial information by the banks and this will be considered in further detail below.

The assets or wealth of a client or the ability to deposit collateral security were further 'objective' means of avoiding risk for a bank. For example, when examining branches which were located in rural districts, banks often listed in detail the amount of land and stock owned by a customer and, most importantly, its value. ${ }^{70}$ Collateral security, although not always required by the banks, was also frequently used as a method for reducing risk on accommodation. This usually took the form of property and land, guarantees, mortgages, or promissory notes and tended to be of the same value of the accommodation extended but often more, especially on large amounts. ${ }^{71}$ The provision of collateral security represented a

\footnotetext{
67 NWGA: NPB, Book of Instructions, 1914, 6492, f. 97 and 103.

68 Wale, 'A neglected aspect', p.4.

69 ibid., p. 2.

70 For example, see NWGA: NPB, Berkeley Branch, Character Book 21218, 1879-1909.

71 Lucy Newton, 'Provincial Banking in Sheffield during the Mid-Nineteenth Century', Papers in Business History, Banks and Customers Institutional Theory and Banking Practises: Banking and Client Relations in Interwar Central Europe and Scandinavia, L.S.E., London (1991); idem. 'Domestic
} 
formalisation of the debt contracted by the borrower. The manager of the Ashton Branch of the Manchester and Liverpool District Bank recorded in the Opinion Book that he 'would not recommend you to trust him without security. I think he has but small means' ${ }^{72}$ In 1907 the Brighton branch of the National Provincial Bank warned that one customer should 'have no overdraft unless properly secured'. ${ }^{73}$ There are numerous other references to collateral security which the bank required to be deposited with them in order to for a customer to obtain credit. ${ }^{74}$

Customers were frequently interviewed by bank managers and visits were undertaken to business premises by bank staff in order to assess the assets, turnover, the quality of security, etc. of a firm. If a business customer held a private account at the same bank, both types of account would be scrutinised. All were further methods by which banks screened and monitored their customers through the sue of 'objective' information.

Thus the banks examined in this study clearly utilised both subjective and objective assessment criteria when assessing applications for credit. Indeed, it may be argued that much of what initially appears to be 'subjective' information was also 'objective' in terms of its relevance to the customers ability to repay credit. However, the exact use of such information, and the weight attributed to different types of data, is unclear. Yet the process of gathering different types of information on which to base decisions is apparent.

Next, it is necessary to consider changes in the information structures of English and Welsh banks over the turn of the century, as the banking sector concentrated and centralised, and the impact this had upon decision-making processes.

Institutional change'; and Duncan Ross, 'Information, Collateral and British Bank Lending in the 1930s' in Cassis, Feldman and Olsson, The Evolution of Financial Institutions and Markets. 25 Jan. 1875, f. 146.

73 NWGA: NPB, Brighton Branch, Information Book, 20521, Apr. 1907, f. 39.

74 NWGA: NPB, Book of Instructions, 6492, 1914, ff. 97 and 103. 
Larger, centralised banks had to cope with far-flung branches: the centre (the bank's head office) needed to extract information from where it was generated (from the peripheral branches) and interpret it in a consistent manner. Did this necessitate increasingly formalised screening and monitoring processes by the banks around the turn of the century? How did the core control the periphery, especially with regard to information flows and lending decisions? Did centralisation lead to more restrictive lending practices? Did head office deal with larger clients and branches deal with smaller customers? ${ }^{75}$

Holmes and Green, in their examination of Midland Bank, assert that 'The drive towards centralised control coloured Midland's business methods' and 'From the late 1890s Midland's branch managers worked to standardised regulations and procedures'. ${ }^{76}$ This can be seen in Appendix B which reproduces a letter to branches instructing branch managers on the form and format in which they should provide opinions to outside agencies, when asked, about branch customers. Furthermore, Appendix A shows the standardisation of customer assessment by the National Provincial Bank in the early twentieth century. A list of broad criteria were provided by which managers were to assess clients applying for accommodation.

However, it was not just centralisation that resulted in changes of bank's lending practice. It has been argued that the City of Glasgow Bank crash in 1878, followed by an associated slump in confidence and business, caused the banks to review and tighten their lending policies and practices. ${ }^{77}$ Holmes and Green describe the process by which Midland Bank 'introduced more formality and professionalism into Midland's banking business' and its lending practices in particular after the 1878 crisis. $^{78}$ A 'Bills Committee' was established by Midland directors to enable them to take increased responsibility for auditing bills;

\footnotetext{
75 The following section draws upon Newton 'Concentration and internationalisation in banking'.

76 Holmes and Green, Midland., p. 112.

77 M. Collins, 'The banking crisis of 1878, Economic History Review, 2nd series, XLII (1989).

78 Holmes and Green, Midland, p. 63.
} 
directors examined quarterly lists of overdrawn accounts; interviews of customers and visits to branches by directors were increased; and outside advisors were appointed. The result, conclude Holmes and Green, was 'a more explicit control over lending.'79

The role of branches remained crucial in the information structure of the banks as they expanded geographically and weathered financial storms. Branches permitted the retention and extension of local knowledge and, in authorising the opening of accounts by customers, they increased deposits. Branches thus remained important nodes of information gathering. Indeed, as amalgamations were undertaken, rather than banks closing branches in order to facilitate economies of scale, they retained and even increased such outlets for their activities. ${ }^{80}$ In 1919, Steele, a banker from the London \& County Bank, maintained that the new branches opened by amalgamated banks resulted in 'bringing credit facilities within easier reach of the small customer in general and the small trader in particular'. ${ }^{81}$

More branches may have brought credit facilities within reach of more customers, but not all developments that arose from increased concentration and control from the centre provided positive developments for customers. An article from the Manchester Guardian in 1904 commented upon the detrimental effects of large banks operating a centralised system. The disadvantages that arose from a loss of local control to a head office in London were discussed.

The moment a chief director loses a firm grasp of every part of the organisation an element of weakness and danger is admitted. In this respect a local combination may be superior to one which has its centre of control in London. ${ }^{82}$

This opinion was reiterated in 1914 when the new, large-scale banks were considered in the Bankers Magazine. The need for strong central control of the 'great' banks was noted but the

\footnotetext{
79 ibid., p. 63.

80 Lucy Newton, and P.L. Cottrell, 'To branch or not to branch? Banking in the English provinces, 1826$1857^{\prime}$ Business and Economic History (November 1998)

$81 \quad B M, 1919$, Vol. 108, p.693.

$82 \quad B M, 1904$, Vol. 78, p. 160.
} 
view was expressed that it was necessary for banks not to 'over-centralise' and that if 'the human factor is allowed full and proper play, all will be well'. ${ }^{83}$

Writing in 1921 with regard to the recent concentration in banking, Lavington was less than complimentary about tighter controls and increasing standardisation of lending practices. He believed that the character of bank accommodation had changed: 'advances are made for shorter periods and against better security'. ${ }^{84}$ Furthermore, he asserted that:

The influential and responsible local banker is replaced by the more mechanically trained branch manager, less well informed on local matters and closely controlled by his general manager, whose sanction must normally be obtained before the grant of an advance of any considerable size. In these circumstances it is inevitable that local knowledge of persons should play a smaller part than formerly in the banks' loan policy and that this policy, being determined rather more by the nature of security offered than by the character and ability of the borrower, should tend to exclude from these borrowers business men who may be unable to offer security for a supply of capital but whose character and abilities give them good social title to its use. ${ }^{85}$

Thus, Lavington urged that the 'subjective' assessment of borrowers should not be forgotten in the rush for greater formalisation and the use of more 'objective' criteria by the large corporate banks.

Holden (Chairman of Midland Bank) argued strenuously against claims that businesses, in particular small-scale firms, were adversely affected by centralisation when giving evidence to the Colwyn Committee in $1918 .{ }^{86}$ He maintained that, in the case of Midland, the system that arose out of amalgamations and concentration actually favoured small businesses and private customers. ${ }^{87}$ Indeed, from the turn of the century Midland Bank required board approval for advances over $£ 2,000$ whereas those below did not and this approach allowed some discretion to branch managers. ${ }^{88}$ However, other banks operated more restrictive

\footnotetext{
$83 \quad B M, 1914$, Vol. 98, p.138.

84 F. Lavington, The English capital market (1921, reprinted by Frank Cass 1968), p. 143.

85 ibid.

86 The Colwyn Committee was established in 1918 in order to examine amalgamations and provide recommendations as to possible future legislation concerning banking concentration. Appointed by the Chancellor of the Exchequer, it comprised Lord Colwyn and a number of leading bankers and industrialists.

87 Holmes and Green, Midland, pp. 129-30.

88 ibid., p. 113.
} 
lending practises at branch level. Branch managers of The London Joint Stock Bank could only sanction advances of a few hundred pounds before referral to head office for approval; the City Bank limit was between $£ 500$ and $£ 1000$ per customer, depending upon the branch; and the London, County and Westminster country manager could only approve accommodation for up to $£ 250$ before 1909 and up to $£ 500$ after that date. 89

Centralisation and standardisation did not necessarily mean increasing detachment from customers. Holmes and Green argue that, following the 1878 bank crisis, by following a 'more systematic approach to lending and the evaluation of securities, Midland's directors and managers became closely involved in the financial development of their major customers.' 90 By the 1880s securities were investigated thoroughly, whereas previously acceptance of securities had been more informal. In 1900, an article in the Bankers Magazine contended that 'purely provincial banks pay less rigid attention to the proper completion of securities than the big London banks with ramifications in the provinces'..$^{91}$ However, the same article asserted that although a new, London head office may 'rectify' such flexible practices regarding security, 'it does not start calling in advances right and left' but rather makes arrangements 'that borrowers feel the change of management as little as may be'. 92

Closer involvement in company finance was also necessary in order to avoid or reduce bad debts that had been incurred during the 1878 crisis. Banks' use of financial information pertaining to business customers had long been common practice but towards the end of the nineteenth century, following the 1878 crisis and the amalgamation movement, more rigorous collection and scrutiny of business customers accounts were undertaken. Wale argues that after 1880 the collection and assessment of customer financial information by all of the major banks became increasingly formalised in an attempt to achieve consistency in

\footnotetext{
89 Cottrell, Industrial Finance, p. 237.

90 ibid., p. 68.

91 BM, 1900, Vol. 70, p.330.

92 ibid.
} 
lending decisions. If a customer was unable to provide a coherent set of company accounts, a branch manager could request that a professionally compiled balance sheet be provided. The bank could go further and request permission for a professional accountant to visit a firm and inspect it's books. The increase in demand from banks for precise and reliable financial information concerning their customers led to increasing work for the professional accountant but many branch managers were also capable of relatively sophisticated interpretation of financial information. ${ }^{93}$

Thus tighter monitoring and controls were introduced after c.1878. The result of such developments upon lending decisions could be viewed as beneficial for the bank and customer - it reduced the risk on lending and built a closer relationship between the bank and customer. However, it could also be seen to be detrimental to borrowing customers as tighter controls could reduce access to credit. This could particularly effect small businesses who had fewer resources at their disposal and were therefore viewed as a greater risk than their larger-scale counterparts.

A statistical analysis by Wale of overdrafts extended by Leicestershire Banking Company both prior to and following its amalgamation with Midland Bank in 1900 shows 'a significant number of customers still borrowing and apparently enjoying good relations with their new bankers'. Figures reveal that there were decreases in the number of overdrafts granted to some industrial sectors in Leicestershire but, Wale argues, 'these were more than compensated for by substantial increases in many others'. Moreover, Midland 'was willing to trust just as many customers as its predecessor to take personal responsibility for advances, thereby forgoing tangible security'. ${ }^{94}$ Continuity of management was also provided in the case of the Leicestershire Banking Company when it's directors continued to serve as an advisory committee to Midland and the former chairman was elected to serve on the board of the Midland in London. ${ }^{95}$ Overall, Wale concludes that Midland head office

\footnotetext{
93 Wale, 'A neglected aspect', p. 5.

94 Wale, 'What help have the banks given British industry?', p. 337.

95 W. F. Crick, and J. E. Wadsworth, A hundred years of joint stock banking (London, 1936), p. 272.
} 
'was not necessarily remote from branches or insensitive to what was happening to its branch customers' and that 'former Leicestershire Banking Co. customers benefited from becoming customers of a larger bank which had a better flow of deposits from which to finance their needs'. ${ }^{96}$ Thus, amalgamation did not necessarily lead to separation from local constituencies or lending practices which were detrimental to local businesses.

In addition to broad changes in the economy and banking sector, it is also important to remember that changes at a micro level could alter lending policy. At branch level, if a Manager was replaced, lending policy could alter dramatically. An example of this can be found at the Tunstall Branch of the National Provincial Bank. In 1901 the branch Manager considered one customer to be 'very industrious and steady' whereas in 1905 a new Manager considered the same customer to have had 'a most very unjustified advance of the late Managers' and to have been a 'source of trouble years ago'. The new manager called in the previous advance of $£ 100 .{ }^{97}$

Throughout much of the amalgamation movement contemporary bankers presented arguments for and against centralisation in their sector of the economy and it's impact upon lending practice and decision-making. However, what was common to all was emphasis on the professional banker practising sound business. 'It has to be remembered that, however great the bank may be, fundamentally it is the "Banker" who counts'. ${ }^{98}$ Therefore, although banks were gaining in size and geographical scope, the judgement of the banker remained essential.

In more recent historical debates, there was has been a general acknowledgement that the smaller provincial banks which predominated before 1880 had been more flexible in their industrial lending, as opposed to the London and provincial branch banks of the early twentieth century which operated a more formal and bureaucratic style of assessing

\footnotetext{
96 Wale, 'What help have the banks given British industry?', p. 338-9.

97 NWGA: NPB, Tunstall Branch, character book, 9966, f.65.

$98 \quad B M, 1914$, Vol. 98, p.138.
} 
customer. ${ }^{99}$ For the majority of the nineteenth century, when banks operated at a local level, the bank's managements, through their participation in local business networks, could personally glean information concerning a customers 'virtue' or reputation. ${ }^{100}$ However, at the beginning of the twentieth century, when banks were operating at a national level in Britain and were dealing with a greatly increased volume of business, methods of gathering information about customers became more formalised. Yet, in the 'Opinion' and 'Character' books the language of the nineteenth century banker remained: customers were still described as 'sound', 'safe' and 'responsible' or, conversely, 'unsound' or 'unreliable'. Therefore, the language of assessment with regard to customers applying for credit appears to have endured throughout the nineteenth and into the early twentieth century. Judgements, and the language utilised by bankers to make such judgements, appear to have remained remarkably consistent, despite the huge contemporary changes which occurred in the banking sector at the turn of the century.

\section{V}

As banks developed towards the modern corporate form they attempted to impose a formalised structure to lending decisions that could be standardised and applied throughout their organisations. Centralisation removed control of lending decisions away from the periphery and to the centre, as London head offices replaced local or region decisionmaking. Decisions were no longer exclusively made by branch managers or by local directors, but instead the manager tended to report to his superiors in London. A geographical distance was thus inserted in the process by which credit applications were appraised and consequently lending decisions were likely to alter. Indeed, an increase in formalisation may be viewed as a result of an increasingly corporate economy in general. However, in the period under examination, the bank archives show very little change in terms of the types of information and the language used in the assessment of potential customer's creditworthiness. It is interesting to note that whilst procedures may have

\footnotetext{
99 For example see R.S. Sayers, Lloyds Bank in the History of English Banking, (Oxford, 1957), p. 271 and Cottrell, Industrial Finance, pp. 236-44.

100 See Newton, 'Regional bank-industry relations' and idem. 'Domestic institutional change'.
} 
changed, the language and judgements of the banker appeared to remain consistent even if, within the realms of this study, it is difficult to ascertain just what impact changes in the banking sector had upon lending outcomes.

Moreover, despite the use of information related to the clients 'virtue' and social principles, it has also been argued here that the judgements regarding these attributes were more likely to be based on property, wealth and a proven track-record for repaying credit rather than a notion of ethics or morality. Or rather, 'virtue' was a proxy for the probity of the client. This was applicable to both the late nineteenth and early twentieth century. Thus, although reputation and trust played an important role, the gathering of information concerning a borrowing customer's ability to, and likelihood of, repaying a loan was paramount. 


\section{Appendix A}

National Provincial Bank, Bradford Branch character book. Instruction for compiling the character book, 1912-1923.

'Means etc. of customers'

Should embody the fullest information obtainable as to:

Stock

Book debt

Investments

Landed and other property - whether encumbered or settled and to what

extent

Debts or liabilities of any kind

Where balance sheets etc. are obtained, these should be record in tabular form in column ruled to admit of ready comparison of various items over a period of several years.

'Misc. information'

Should be include any data that may be of use in interviewing the account including:

Surety obligations

Client's business habits

Character and connections (if of value)

Arrangements made for the conduct of the account, etc. ${ }^{101}$

101 NWGA: NPB, Bradford Kirkgate branch, Character Book, 1912-1923, 09431. 


\section{Appendix B \\ Letter to branches of Midland Bank concerning the correct procedure of providing 'opinions' of customers to external organisations}

H.O.

29th April 1910

\section{Opinions}

Dear Sir,

In giving opinions, we shall be glad if you will discontinue your present method and adapt that which is in general use throughout the system with the exception of the North \& South Wales Bank Branches.

Opinions must not be given in any other manner, excepting verbally, where such is the custom, than that provided by the Bank's printed memorandum Form No. 570. The Name of the Branch, the date, the name and address of the correspondent and the initials (not the name) of the person enquired about are to be inserted. The opinion is to be written at the end of the Form, but no signature or initial (on behalf of the Bank) is to be appended. The form is to be sent out entirely unsigned and uninitialed, so that the identity of the Bank is shown only by the addressed heading of the Form./ In giving an opinion, the reply must commence with 'Are considered to be etc.' and not 'We believe them to be, etc.,'.

In cases where the Debentures of a Company enquired about are held by the Bank, if time will permit, the enquiry should be submitted to Head Office before replying, other wise a verbal reply should be given wherever practicable, but on sending a written answer Form No. 570 must be used as mentioned above. If the concern is very weak it will generally be advisable to say 'that they are short of capital and have debentures issues', but an endeavour should be made to avoid giving any information whatever if at all possible. In future, a record of all opinions given in respect of customers of the Branch must be made in the 'Opinions Given' Book, a suitable place being allotted to each customer in order that any subsequent reports may be entered under the heading of the respective customers. The entry in this book should be installed by the Manager or other officer giving the opinion.

We enclose a specimen of Form. No. 570 and have asked the Stationery Dept. to forward you a supply together with the 'Opinions given' Book.

We shall be glad to hear when the same have reached you and the foregoing is understood.

Sam. B. Murray

Joint General Manager 